\author{
Stanisław Lachowski *, Magdalena Florek-Łuszczki **, Anna Jurkiewicz ***, \\ Jarosław Chmielewski ${ }^{* * *}$, llona Żeber-Dzikowska ${ }^{* * * * *}$
}

\title{
Genetically modified organisms (GMO) in opinions completing secondary schools in Lublin
}

\section{Genetycznie modyfikowane organizmy (GMO) w ocenie maturzystów Lubelszczyzny}

\begin{abstract}
* Dr hab. Stanisław Lachowski - Institute of Rural Health, Jaczewskiego 2 St., 20-090 Lublin; Maria Curie Skłodowska University, Marii CurieSkłodowskiej 5 Sq., 20-031 Lublin; e-mail: stlachowski@wp.pl

** Dr Magdalena Florek-Łuszczki - Institute of Rural Health, Jaczewskiego 2 St., 20-090 Lublin, e-mail: magdalena.florek@wp.pl

*** Dr Anna Jurkiewicz - Consultrix Lublin, Szeligowskiego 8/97 St., 20-883

**** Dr Jarosław Chmielewski - Institute of Environmental Protection National Research Institute, Krucza 5/11d St., 00-548 Warsaw

${ }_{* * * * *}$ Dr hab. Ilona Żeber-Dzikowska, prof. nadzw., Institute of Humanities and Social Sciences, The State School of Higher Professional Education in Płock, Gałczyńskiego 28 St., 09-400 Płock; Institute of Biology, the Jan Kochanowski University in Kielce, Świetokrzyska 15 St., 25-406 Kielce
\end{abstract} Lublin

Keywords: GMO, adolescents, secondary school graduates, emotions, opinions, evaluations

Słowa kluczowe: GMO, młodzież, maturzyści, emocje, opinie, oceny

\section{Abstract}

The objective of the conducted analysis is the opinion of adolescents completing secondary schools concerning genetically modified organisms (GMO) and determination of the relationship between the level of knowledge concerning GMO, and evaluation of the safety of their use in industry and agriculture.

The scope of problems undertaken was elaborated based on the survey studies conducted on a group of 500 adolescents completing secondary schools from the Lublin Region, including 250 attending general profile secondary schools and 250 from agricultural technical schools. The study was conducted by the method of a diagnostic survey, using the questionnaire technique. The results of the study showed that the respondents perceived both positive and negative aspects of producing genetically modified (GM) products. These evaluations were significantly related with the respondents' level of knowledge concerning GMO. The higher the level of knowledge, the more positive the evaluations of the adolescents concerning the cultivation and breeding of $\mathrm{GMO}$, and more frequent indications that the consumption of products manufactured from these organisms is safe.

๑) IOŚ-PIB

\section{INTRODUCTION}

The concept of genetically modified organisms (GMO) evokes various emotions. To a large extent, they result from the level of knowledge possessed concerning the method of breeding organisms with the use of genetic engineering. Special concerns are related with the potential health consequences that may occur after the consumption by humans of genetically modified (GM) products.

Genetic engineering is an increasingly thriving domain of science, which is widely applied, among others, in the agricultural, pharmaceutical sectors, and medicine. Transgenic organisms obtained in this way show a greater resistance to diseases and unfavourable weather conditions, which considerably enhances the effectiveness of agricultural production [Gawęcki 2002,

\section{Streszczenie}

Celem przeprowadzonych analiz jest poznanie opinii młodzieży licealnej na temat GMO oraz określenie związku pomiędzy poziomem wiedzy na temat GMO a oceną bezpieczeństwa ich wykorzystania w przemyśle i rolnictwie.

Podjętą problematykę opracowano na podstawie badań ankietowych przeprowadzonych w grupie 500 maturzystów z województwa lubelskiego, w tym 250 uczniów Liceum Ogólnokształcących i 250 uczniów Techników Rolniczych. Badania przeprowadzono metodą sondażu diagnostycznego, za pomocą kwestionariusza ankiety.

Przeprowadzone badania wykazały, że respondenci dostrzegają zarówno pozytywne, jak i negatywne aspekty wytwarzania produktów GM. Oceny te pozostają w istotnym związku z poziomem wiedzy respondentów na temat organizmów MG. Im wyższy poziom wiedzy tym młodzież bardziej pozytywnie ocenia uprawy i hodowlę organizmów GM, a także częściej wskazuje, że spożywanie produktów wytworzonych z tych organizmów jest bezpieczne.

Kuiper et al. 2001]. An increase in the quantity and quality of the cultivated GMO does not evoke many reservations; however, the sole process of obtaining transgenic organisms, consisting in the transition of DNA fragment to another, foreign organism [Roszkowski 2007, Więckowski 2008], causes a number of concerns, fears, and doubts.

Those who are critical with respect to GMO express concerns pertaining to the potential threats resulting from the possibility of uncontrolled penetration of dangerous transgenes to the natural environment, as well as concerns about the effect of GM food on human health [Runge, Jackson 2000, Crawley et al. 2001, Cook et al. 2002, Cardello 2003, Dąbrowski, Twardowski 2007]. In the group of most frequently mentioned threats to human 
health resulting from the consumption of this food are: decreased fertility, hematologic, metabolic, and immune disorders, as well as increased resistance to antibiotics and increased incidence of cancerous diseases [Kosicki, Kosicka-Gębska 2012].

In turn, the supporters of GMO, who express positive opinions concerning the use of genetic engineering in practice, emphasise that they serve to improve the quality of products, and the process of their production is subject to restrictive standards of safety, which minimises the risk of unfavourable consequences for the human body [Skawińska, Blicharska 2012, Twardowski 2007].

The presented article demonstrates the results of studies conducted among the adolescents completing secondary schools from the Lublin Region. The objective of study was the adolescents' evaluations concerning GMO. The goal of the analyses was the recognition of opinions of secondary school graduates concerning the scope of problems and benefits related with GMO, and the determination of relationship between the opinions on GMO and the selected demographic characteristics of the adolescents examined. A hypothesis was adopted that the evaluations of GMO differ according to characteristics such as gender, place of residence, and type of family environment, as well as education profile (general or technical secondary school), and the respondents' knowledge concerning GMO.

\section{MATERIAL AND METHOD}

The study was conducted in the Lublin Region among secondary school graduates in two types of secondary schools: general profile and technical schools of agricultural profile. The study covered a group of 500 adolescents -250 adolescents from each type of school (Tab. 1). Among the adolescents in the study, girls constituted a slightly larger group (58.4\%) than boys $(41.6 \%)$. The majority of respondents were rural inhabitants $-73.4 \%$, only $26.6 \%$ of school adolescents lived in the urban areas; more than a half of the adolescents $(51.8 \%)$ came from agricultural families, while the reminder (48.2\%) from non-agricultural families.

The study was conducted by the method of a diagnostic survey using the questionnaire technique. The questionnaire contained items concerning individual components of attitudes towards GMO (knowledge, emotional-evaluative attitude, behaviours), and questions pertaining to the socio-demographic characteristics of the examined adolescents.

The collected research material was subjected to statistical analysis. The hypotheses were verified using the statistical $\chi^{2}$ test, Man-Whitney $U$ test, and linear regression analysis was performed using the stepwise method.

\section{RESULTS AND DISCUSSION}

The emotional-evaluative attitudes towards GMO and products manufactured based on these organisms concern many aspects of this scope of problems. Evaluations in this respect greatly vary, not only on the scale of large communities of Polish society, but also among specialists who in a professional way analyse the benefits and threats resulting from GMO. Considering the complexity of evaluations in this area, an attempt was undertaken to recognise the opinions of adolescents completing secondary
Table 1. Degree of acceptance for negative and positive effects of GMO.

\begin{tabular}{|c|c|c|c|c|c|c|}
\hline $\begin{array}{c}\text { Effect of } \\
\text { GMO }\end{array}$ & \multicolumn{2}{|c|}{$\begin{array}{c}\text { General } \\
\text { profile school }\end{array}$} & \multicolumn{2}{|c|}{$\begin{array}{c}\text { Technical } \\
\text { school }\end{array}$} & \multicolumn{2}{|c|}{$\begin{array}{c}\text { Mann-Whitney } \\
\text { test }\end{array}$} \\
\cline { 2 - 4 } & Mean & $\begin{array}{c}\text { Mean } \\
\text { rank }\end{array}$ & Mean & $\begin{array}{c}\text { Mean } \\
\text { rank }\end{array}$ & U & p \\
\hline $\begin{array}{c}\text { Mean } \\
\text { indicator of } \\
\text { acceptance } \\
\text { of negative } \\
\text { opinions }\end{array}$ & 2.9 & 267.27 & 2.7 & 212.59 & $22,228.0$ & 0.000 \\
$\begin{array}{c}\text { Mean } \\
\text { indicator of } \\
\text { acceptance } \\
\text { of positive } \\
\text { opinions }\end{array}$ & 3.1 & 270.84 & 2.8 & 188.11 & $17,007.5$ & 0.000 \\
\hline
\end{tabular}

schools about both the positive and negative consequences of genetic modifications, and obtaining knowledge on the way of evaluation of the selected aspects of GMO.

The recognition of opinions of young people about GMO was justified by the belief that they are open to the acquisition of reliable knowledge and able to provide balanced opinions. In addition, this is a large group of consumers who in a short time will start their own households and will make decisions concerning the selection of products to satisfy the needs of their members.

Adolescents completing secondary schools in the Lublin Region were asked to provide their opinions concerning 8 negative and 12 positive statements on GMO. The respondents determined acceptance for each opinion according to a 4-grade scale (1 - I do not agree, 2 - I rather not agree, 3 - I rather agree, and 4 - I agree).

The average level of acceptance for positive opinions concerning GMO was slightly higher than that for negative opinions (Tab. 1). The differences were statistically insignificant, which indicates that the adolescents, to a similar degree, perceive both benefits and threats resulting from genetic modification of organisms. The mean values of indicators of acceptance (close to the value 3 ) confirm that, in general, the respondents rather agreed with the presented opinions.

Among the negative opinions, the highest level of acceptance was obtained with respect to statements that genetic modification will result in new diseases in the animal world, and the disappearance of traditional animal and plant species, as well as the disappearance of biodiversity. To the lowest degree, the opinion was accepted that the presence of risk was related with the loss of control over the spread of GMO.

While evaluating the positive aspects of GMO, the adolescents, to the highest degree, shared opinions that the cultivation of GM plants brings about higher yields and is more profitable, and that GM plants and animals are more resistant to diseases. At the same time, to the lowest degree, they agreed with the opinion that the cultivation of GM plants will limit the contamination of the natural environment.

The attitudes towards the positive and negative opinions concerning GMO significantly differed in the sub-groups of adolescents, divided according to the type of school they 
Table 2. Evaluation of various aspects of genetic modifications (GMO) according to the type of school attended by adolescents.

\begin{tabular}{|c|c|c|c|c|c|c|}
\hline & \multicolumn{4}{|c|}{ Type of school } & \multicolumn{2}{|c|}{ In general } \\
\hline & \multicolumn{2}{|c|}{ General profile } & \multicolumn{2}{|c|}{ Agricultural profile } & \multirow{2}{*}{$\mathbf{N}$} & \multirow{2}{*}{$\%$} \\
\hline & $\mathbf{N}$ & $\%$ & $\mathbf{n}$ & $\%$ & & \\
\hline \multicolumn{7}{|c|}{ Opinion on cultivation of GM plants } \\
\hline Negative & 150 & 60.4 & 147 & 59.3 & 297 & 59.9 \\
\hline Positive & 98 & 39.6 & 101 & 40.7 & 199 & 40.2 \\
\hline In general & 248 & 100.0 & 248 & 100.0 & 496 & 100.0 \\
\hline \multicolumn{7}{|c|}{ Opinion of breeding GM animals } \\
\hline Negative & 165 & 66.8 & 165 & 66.5 & 330 & 66.7 \\
\hline Positive & 82 & 33.2 & 83 & 33.4 & 165 & 33.4 \\
\hline In general & 247 & 100.0 & 248 & 100.0 & 495 & 100.0 \\
\hline \multicolumn{7}{|c|}{ Opinions on food manufactured based on GMO } \\
\hline Negative & 167 & 67.3 & 155 & 62.5 & 322 & 64.9 \\
\hline Positive & 81 & 32.6 & 93 & 37.5 & 174 & 35.1 \\
\hline In general & 248 & 100.0 & 248 & 100.0 & 496 & 100.0 \\
\hline \multicolumn{7}{|c|}{ Opinion on achievements of engineering with respect to $\mathrm{GMO} \chi^{2}=8.774, p<0.05$} \\
\hline Negative & 129 & 52 & 143 & 57.6 & 272 & 54.8 \\
\hline Positive & 119 & 48 & 105 & 42.3 & 224 & 45.1 \\
\hline In general & 248 & 100.0 & 248 & 100.0 & 496 & 100.0 \\
\hline \multicolumn{7}{|c|}{ Opinion on the health value of food manufactured based on GMO } \\
\hline Dangerous & 151 & 60.4 & 149 & 59.9 & 300 & 60.1 \\
\hline Safe & 99 & 39.6 & 100 & 40.2 & 199 & 39.9 \\
\hline In general & 250 & 100.0 & 249 & 100.0 & 499 & 100.0 \\
\hline
\end{tabular}

attended. The overall indicator of acceptance of both positive and negative opinions was significantly higher in the group of adolescents attending secondary schools of a general profile, than that among those from agricultural technical schools.

The adolescents in the study also evaluated the selected aspects of activity related with $\mathrm{GMO}$, including the production of $\mathrm{GM}$ plants and animals, production of food manufactured based on $\mathrm{GMO}$, and the achievements of genetic engineering. The majority of respondents negatively evaluated (negatively, or rather negatively) all the mentioned aspects of activity (Tab.2). The largest number of respondents negatively evaluated the breeding of GM animals $(66.7 \%)$ and the use of GMO for the production of food $(64.9 \%)$. In addition, the largest number of respondents $(60.1 \%)$ expressed an opinion that food containing raw materials from GMO is rather dangerous or definitely dangerous for human health. It is noteworthy that every fourth adolescent in the study definitely negatively evaluated the breeding of GM animals (26.5\%), and every fifth $(20.4 \%)$ - the cultivation of GM plants. Few respondents definitely positively evaluated GMO. The lowest percentage of such evaluations was observed with respect to food manufactured based on GMO. Such food was positively evaluated by $2.6 \%$ of adolescents, and only eight of them $(1.6 \%)$ admitted that such food is entirely safe for human health. A low percentage of respondents (approximately 7\%) positively evaluated the breeding of GM animals and cultivation of GM plants, and a still a lower percentage $(5.2 \%)$ fully positively evaluated the achievements of genetic engineering.

The evaluations of adolescents attending schools of general and agricultural profiles concerning GMO were generally similar. A significant difference was observed only with respect to attitude towards the achievements of genetic engineering. This form of interference with live organisms was evaluated in higher terms by adolescents from schools of general profile than those from agricultural technical schools (Tab. 2).

Considering all the analysed aspects of the adolescents' attitudes towards GMO, it should be presumed that those attending schools of general profile formulated more explicit opinions than the adolescents from agricultural schools. This concerned both positive and negative evaluations. It should be presumed that this relationship was related with the state of the adolescents' knowledge of the problem. An analysis of the results of studies confirmed that the adolescents from schools of a general profile were more interested in the scope of problems concerning GMO and possessed a higher level of knowledge than their contemporaries from agricultural schools [Florek-Łuszczki et al. 2016]. While seeking factors conditioning the adolescents' opinions and evaluations concerning GMO, a hypothesis was adopted that the evaluations in this respect are related with 
Table 3. Models of conditioning of evaluations of various aspects of genetic modifications (GMO) (results of multiple linear regression analysis by the stepwise method).

\begin{tabular}{|c|c|c|c|c|c|c|c|c|}
\hline \multirow{2}{*}{$\begin{array}{c}\text { Evaluation } \\
\text { indicators } \\
\text { (explanatory } \\
\text { variable) }\end{array}$} & \multirow{2}{*}{ Predictors } & \multicolumn{2}{|c|}{ ANOVA } & \multicolumn{2}{|c|}{$\begin{array}{c}\text { Coefficients } \\
\beta\end{array}$} & \multirow{2}{*}{$\mathbf{t}$} & \multirow{2}{*}{$\mathbf{p}$} & \multirow{2}{*}{$\mathbf{R}^{2}$} \\
\hline & & $\mathbf{F}$ & p & Non-standardised & Standardised & & & \\
\hline $\begin{array}{l}\text { Evaluation of } \\
\text { GMO plant } \\
\text { cultivation }\end{array}$ & $\begin{array}{l}\text { (constant) } \\
\text { Self-reported level } \\
\text { of knowledge } \\
\text { concerning GMO }\end{array}$ & 12.234 & 0.001 & $\begin{array}{l}1.863 \\
0.187\end{array}$ & 0.164 & 3.498 & 0.001 & 0.164 \\
\hline $\begin{array}{l}\text { Evaluation of } \\
\text { GMO animals } \\
\text { breeding }\end{array}$ & $\begin{array}{l}\text { (constant) } \\
\text { Self-reported level } \\
\text { of knowledge } \\
\text { concerning GMO } \\
\text { Gender }\end{array}$ & 6.297 & 0.002 & $\begin{array}{l}1.502 \\
0.180 \\
0.189\end{array}$ & $\begin{array}{l}0.138 \\
0.105\end{array}$ & $\begin{array}{l}8.135 \\
\\
2.936 \\
2.241\end{array}$ & $\begin{array}{l}0.000 \\
0.000 \\
0.011\end{array}$ & 0.166 \\
\hline $\begin{array}{l}\text { Evaluation of } \\
\text { health safety } \\
\text { related with } \\
\text { GMO }\end{array}$ & $\begin{array}{l}\text { (constant) } \\
\text { Self-reported level } \\
\text { of knowledge } \\
\text { concerning GMO } \\
\text { Type of school }\end{array}$ & 9.579 & 0.000 & $\begin{array}{c}2.762 \\
0.133 \\
-0.197 \\
0.130\end{array}$ & $\begin{array}{c}0.146 \\
-0.116 \\
0.103\end{array}$ & $\begin{array}{r}13.421 \\
33.088 \\
-2.396 \\
\\
2.080\end{array}$ & $\begin{array}{l}0.000 \\
0.002 \\
0.017 \\
0.038\end{array}$ & 0.247 \\
\hline $\begin{array}{c}\text { Evaluation of } \\
\text { food containing } \\
\text { GMO }\end{array}$ & $\begin{array}{l}\text { (constant) } \\
\text { Self-reported level } \\
\text { of knowledge } \\
\text { concerning GMO } \\
\text { Interest in GMO }\end{array}$ & 6.270 & 0.000 & $\begin{array}{c}1.900 \\
0.121 \\
0.113 \\
-0.083\end{array}$ & $\begin{array}{c}0.117 \\
0.114 \\
-0.103\end{array}$ & $\begin{array}{c}14.481 \\
2.396 \\
2.330 \\
-2.202\end{array}$ & $\begin{array}{l}0.000 \\
0.017 \\
0.020 \\
0.028\end{array}$ & 0.201 \\
\hline $\begin{array}{l}\text { Overall } \\
\text { indicator } \\
\text { of GMO } \\
\text { evaluation }\end{array}$ & $\begin{array}{l}\text { (constant) } \\
\text { Self-reported level } \\
\text { of knowledge } \\
\text { concerning GMO } \\
\text { Interest in GMO }\end{array}$ & 9.797 & 0.000 & $\begin{array}{l}1.774 \\
0.122 \\
0.100\end{array}$ & $\begin{array}{l}0.127 \\
0.116\end{array}$ & $\begin{array}{c}16.164 \\
2.466 \\
2.259\end{array}$ & $\begin{array}{l}0.000 \\
0.014 \\
0.024\end{array}$ & 0.206 \\
\hline
\end{tabular}

Codes for dichotomous variables:

Gender: 1 - female, 2 - male; Type of school: 1 - General profile, 2 - Agricultural profile

three groups of factors: (1) interest in the scope of problems pertaining to $\mathrm{GMO}$, (2) level of knowledge concerning $\mathrm{GMO}$, and (3) demographic characteristics of the respondents.

In order to determine which of the predictors mentioned are significantly related with the evaluation of genetic modification of organisms, multiple linear regression analysis was applied using the stepwise method of introduction of predictors. The analysis was applied with respect to the three groups of dependent variables specifying the opinions and evaluations concerning GMO: (1) evaluation of various aspects of genetic modifications, (2) level of acceptance for positive opinions on GMO, and (3) level of acceptance for negative opinions on GMO. For each analysis, an identical set of eight independent variables was introduced ${ }^{1}$. Independent nominal variables were converted into dichotomous variables.

The regression analysis performed showed that only a few variables were significantly related with the adolescents' opinions and evaluations concerning GMO. The adolescents' interest in the scope of problems related with GMO and self-reported state of knowledge of this problem exerted the greatest effect on the

\footnotetext{
IIndependent variables: gender, place of residence, work of parents, type of school, self-assessment of knowledge about GMOs, the level of interest in the GMO, and assessment of the level of knowledge about GMOs.
}

evaluations of various aspects of genetic modifications. The presumption that these relationships depend on the respondents' place of residence (rural or urban) and type of parents' work (Tab. 3) were not confirmed.

The evaluations pertaining to the breeding of animals and cultivation of GM plants were positively correlated $(\beta>0)$ with self-reported level of adolescents' knowledge concerning GMO, which means that the more positive the adolescents' evaluations of their knowledge on GMO, the more positive opinions they expressed concerning cultivation and breeding of GMO. Selfreported knowledge was also significantly, positively correlated with the evaluation of safety of consumption of food containing GM products and evaluation of the health value of food manufactured based on GMO. A higher self-reported level of knowledge was accompanied by the belief that food containing GMO is safe for human health. The opinions on GMO were also influenced by the level of adolescents' knowledge measured by the number of correct answers provided with relation to this problem. A higher level of knowledge was accompanied by a higher probability of occurrence of a positive opinion concerning the safety of consumption of food containing GMO; however, it simultaneously increases the probability of negative opinions evaluating this type of food. Thus, it may be presumed that persons possessing a 
Table 4. Models of conditioning of the level of acceptance for negative and positive opinions on GMO.

\begin{tabular}{|c|c|c|c|c|c|c|c|c|}
\hline \multirow{2}{*}{$\begin{array}{c}\text { Level of } \\
\text { acceptance } \\
\text { for opinions } \\
\text { concerning GMO }\end{array}$} & \multirow{2}{*}{ Predictors } & \multicolumn{2}{|c|}{ ANOVA } & \multicolumn{2}{|c|}{$\begin{array}{c}\text { Coefficients } \\
\beta\end{array}$} & \multirow{2}{*}{$\mathbf{t}$} & \multirow{2}{*}{$p$} & \multirow{2}{*}{$\mathbf{R}^{2}$} \\
\hline & & $\mathbf{F}$ & p & Non-standardised & Standardised & & & \\
\hline Negative opinions & $\begin{array}{c}\text { (constant) } \\
\text { Self-reported } \\
\text { knowledge on GMO } \\
\text { Gender } \\
\text { Self-reported } \\
\text { knowledge on GMO } \\
\text { Type of school }\end{array}$ & 11.162 & 0.000 & $\begin{array}{c}2.902 \\
0.103 \\
-0.133 \\
0.064 \\
-0.125\end{array}$ & $\begin{array}{c}0.133 \\
-0.127 \\
0.116 \\
-0.122\end{array}$ & $\begin{array}{c}21.584 \\
2.721 \\
-2.635 \\
2.441 \\
-2.416\end{array}$ & $\begin{array}{l}0.000 \\
0.007 \\
0.009 \\
0.015 \\
0.016\end{array}$ & 0.307 \\
\hline Positive opinions & $\begin{array}{c}\text { (constant) } \\
\text { Self-reported } \\
\text { knowledge on GMO } \\
\text { Type of school } \\
\text { Gender } \\
\text { Interest in GMO }\end{array}$ & 22.517 & 0.000 & $\begin{array}{c}2.539 \\
0.147 \\
-0.279 \\
0.160 \\
0.066\end{array}$ & $\begin{array}{c}0.193 \\
-0.270 \\
0.152 \\
0.097\end{array}$ & $\begin{array}{c}18.839 \\
3.556 \\
-5.640 \\
3.304 \\
1.974\end{array}$ & $\begin{array}{l}0.000 \\
0.000 \\
0.000 \\
0.001 \\
0.049\end{array}$ & 0.463 \\
\hline
\end{tabular}

Codes for dichotomous variables:

Gender: 1 - female, 2 - male; Type of school: 1 - General profile, 2 - Agricultural profile

greater scope of knowledge on GMO, to a lower degree perceive a risk for health caused by GMO, however, generally evaluate food manufactured based on these organisms in more negative terms.

The adolescents' acceptance for negative and positive opinions concerning GMO is also significantly correlated with the intellectual component of an attitude (Tab. 4). The probability of acceptance of both negative and positive opinions was higher, the probability of acceptance of negative as well as positive opinions is the bigger the young people better assess the level of their knowledge.. At the same time, positive opinions were more frequently accepted when adolescents showed a greater interest in GMO, and negative when the adolescents had a greater scope of information concerning this problem. The acceptance of positive and negative opinions was also significantly correlated with the respondents' gender and the profile of school attended by the adolescents. The acceptance for both positive and negative opinions was higher among the adolescents from schools of general profile than those from agricultural schools. Positive opinions were more often shared by boys than girls; whereas girls more often agreed with the negative opinions.

\section{SUMMING UP}

The results of the study showed that respondents perceived both positive and negative aspects of manufacturing GM products. The adolescents' positive evaluations and acceptance referred only to those scientific studies within genetic engineering which are biased towards the development of medical, pharmaceutical knowledge, and the knowledge that serves the protection of the natural environment.

The respondents' negative attitude was related primarily with concern about the occurrence of potential disorders in the functioning of the natural ecosystem and the occurrence of new diseases among animals. The majority of respondents expressed a definite or moderate objection to genetic modification of plants and animals designed for human food (approx. 65\%). In the opinions of nearly $2 / 3$ of the adolescents, the manufacturing of food products based on GMO is harmful and dangerous for human health.

These opinions are consistent with the opinions of the majority of Polish society. According to the studies by the Public Opinion Research Centre, $66 \%$ of the respondents expressed the belief that the cultivation of GM plants is an important scientific achievement [Poles about food safety and GMO. Report from studies, 2013]. At the same time, the great majority of the examined Poles (approx. $70 \%$ ) mentioned that GMO may exert a negative effect on human health [Poles regarding GMO. Report from studies, 2012, Poles about food safety and GMO. Report from studies, 2013]. It is noteworthy that in the food industry, gene modifications are applied on over 60 plant species, and their primary goal is increasing resistance to pest, improvement of taste and nutritional value [Pietrzyk, Błoniarczyk 2007, Buchowicz 2009, Kosicki, Kosicka-Gębska 2012].

Studies conducted among the adolescents completing secondary schools showed that both positive and negative evaluations of GMO, were correlated with self-reported level of the respondents' knowledge concerning the process of their production and use. The higher the adolescents' evaluated their scope of knowledge concerning GMO, the more positive their attitude towards cultivation and breeding of $\mathrm{GMO}$, as well as towards the safety of consumption of products manufactured from these organisms. A positive relationship between the level of knowledge concerning genetic modifications and acceptance for scientific activity in the field of genetic engineering, and towards products manufactured with its use, is characteristic for the majority of consumers. Studies of consumer preferences indicated that the most important determinant of choices made, especially from the aspect of assessment of the risk related with potential food products, is knowledge on their origin and method of production, 
as well as duration of the functioning on the food market [Nocella, Kennedy 2012, Mahon et al. 2006, Verbeke et al. 2006].

The results of studies among the secondary school adolescents show that it is necessary to carry out reliable education concerning the process of production of GMO and their use. The presentation in a precise and accessible way of both the benefits and threats resulting from the use of GMO in industry and agriculture, would provide an opportunity to make rational choices based on in-depth knowledge, which, as has resulted from studies, shapes our emotional-evaluative attitudes.

\section{REFERENCES}

BUCHOWICZ J. 2009. Biotechnologia molekularna. Modyfikacje genetyczne, postępy, problemy. Wyd. Naukowo-Techniczne, Warszawa.

CARDELLO A. 2003. Consumer concerns and expectations about novel food processing technologies: Effects on product liking. Appetite 40: 217-233.

COOK A. J., KERR G. N., MOORE K. 2002. Attitudes and intentions towards purchasing GM food. Journal of Economic Psychology. 23, 5, October: 557-572.

CRAWLEY M.J., BROWN S.L., HAILS R.S. I WSP. 2001. Transgenic crops in natural habitats. Nature. 409: 682-683.

DĄBROWSKI Z. T., TWARDOWSKI T. 2007. GMO Wprowadzenie. Kosmos: Problemy Nauk Biologicznych. 56; (3-4): 209-211.

FLOREK-ŁUSZCZKI M, LACHOWSKI S., CHMIELEWSKI J., JURKIEWICZ A. 2016. Knowledge of adolescents completing secondary schools concerning genetically modified organisms (GMO). Edukacja Ustawiczna Dorosłych. 93, 2.

GAWĘCKI J. 2002. Żywność nowej generacji a racjonalne żywienie, Żywność. Nauka. Technologia. Jakość. 3, 4: 5-15.

KUIPER A.H., KLETER A.G., NOTEBORN P.J., KOK E.J. 2001. Assessment of the food safety issues related to genetically modified foods. The Plant Journal 27, 6: 503-528.

KOSICKI J., KOSICKA-GĘBSKA M. 2012. Rośliny GMO i żywność genetycznie modyfikowana - nowość wzbudzająca ciekawość, nadzieje i obawy, Acta Scientifica AcaDemiae Ostroviensis, Zeszyty Naukowe Sectio A - 1, 1: 135-149.

MAHON D., COWAN C., McCARTHY M. 2006. The role of attitudes, subjective norm, perceived control and habit in the consumption of ready meals and takeaways in Great Britain. Food Quality and Preference 17: 474-481.
NOCELLA G., KENNEDY O. 2012. Food health claims - What consumers understand. Food Policy 37: 520-529.

PIETRZYK S., BŁONIARCZYK K. 2007. Żywność genetycznie modyfikowana, Laboratorium 9: 34-38.

Poles about food safety and GMO. Report from studies, 2013, CBOS, Warszawa ["In Polish"].

Poles regarding GMO. Report from studies, 2012, TNS Pentor, Warszawa [In Polish"].

ROSZKOWSKIA. 2007. Technika rolnicza a GMO (Biotechnologia - Bioinżynieria-Rośliny transgeniczne), Inżynieria Rolnicza 8, 96: 219-224.

RUNGE C.F., JACKSON L.A .2000. Negative labeling of genetically modified organisms (GMOs): the experience of rBST, Ag Bio Forum - 3, 1: 58-62.

SKAWIŃSKA M., BLICHARSKA J. 2012. Genetycznie modyfikowane rośliny - zagrożenie czy korzyści, Studia Medyczne 27, 3: 73-81.

TWARDOWSKI T. 2007. Opinia publiczna a GMO. Biotechnologia 3, 78: 45-65.

VERBEKE W., FREWER L.J., SCHOLDERER J., de BRABANDER H.F. 2006. Why consumer behave as they do with respect to food safety and risk information. Analytica Chimica Acta 586: 2-7.

WIĘCKOWSKI S.K. 2008. Genetycznie Modyfikowane Organizmy (GMO) - obietnice i mity. Wyd. Ekonomia i Środowisko, Białystok. 